\title{
Green synthesis of silver nanoparticles mediated by Coccinia grandis and Phyllanthus emblica: a comparative comprehension
}

\author{
Vasanth Nayagam ${ }^{1} \cdot$ Melchias Gabriel $^{1} \cdot$ Kumaravel Palanisamy ${ }^{2}$
}

Received: 6 February 2017 / Accepted: 21 March 2018 / Published online: 4 April 2018

๑) Springer-Verlag GmbH Germany, part of Springer Nature 2018

\begin{abstract}
Fruit extracts also have the potentiality to synthesize silver nanoparticles, which serve as antimicrobial agent in the biological field. At present, the field of biomedical largely depends on the biosynthesized NPs to fight against the multi-drug-resistant pathogens. The fruit residue of Coccinia grandis and Phyllanthus emblica are employed for synthesizing AgNPs by green method. The NPs are further subjected to UV, FTIR, SEM, and XRD measurements. The ten different pathogens were tested against the AgNPs synthesized. The same were tested for early growth of some seed variety too, so as to check the advantages of AgNPs. The UV spectrum analysis showed $442 \mathrm{~nm}$ and $423 \mathrm{~nm}$, respectively, and FTIR peaks for the functional group that is responsible for the conversion of NPs were observed at 1640.02 for N-H bond amines (Coccinia grandis) and at 1637.45 for N-H bond amines (Phyllanthus emblica). The SEM results also illustrated that AgNPs are spherical in shape. The XRD patterns indicate the crystalline nature of the AgNPs formed with both these plants. The antimicrobial assay of AgNPs from Coccinia grandis shows maximum zone of inhibition $(14 \mathrm{~mm})$ for Vibrio cholerae whereas the AgNPs from Phyllanthus emblica show maximum inhibition at distinct points, namely for Staphylococcus aureus, Vibrio cholerae, Salmonella typhi, and Proteus mirabilis $(12 \mathrm{~mm})$. Seed germination initiated by AgNPs is quiet effective and healthier compared to the waterinduced seeds. Hence, biogenic AgNPs have various applications in favour of human society.
\end{abstract}

Keywords Nanoparticles $\cdot$ Germination $\cdot$ Anti-microbial $\cdot$ Crystalline $\cdot$ Inhibition

\section{Introduction}

The present society largely depends on the nanoproducts since than its worldwide recognition. The applications of NPs suitably adapted due to various sciences have been inculcated such as nanotechnology and nanobiotechnology. To define this fine science, it is the manipulation of matter on atomic and molecular scales often nano denoted as billionth $\left(10^{-9}\right)$. Hence, the entire process and systematic

Vasanth Nayagam

vasanthresearchsjc@gmail.com

Melchias Gabriel

gbmelchias@gmail.com

Kumaravel Palanisamy

kumaravelbiotech@gmail.com

1 Department of Botany, St. Joseph's College

(Autonomous), Affiliated to Bharathidasan University,

Tiruchirappalli 620 002, India

2 Department of Biotechnology, Vysya College, Salem, Tamil Nadu 636 103, India evaluation is confined to operate at a scale of $100 \mathrm{~nm}$ (Asha et al. 2016). The particles be capable of be synthesized via physical, chemical, and biological technique. The metallic nanoparticles from Silver $(\mathrm{Ag})$, Gold $(\mathrm{Au})$, Platinum $(\mathrm{Pt})$, and Palladium (Pd) play a fundamental role in the relevance of the substances. In addition, AgNPs are being highly focused in the field of life science and have become the choice of researcher's interest that has been often recalibrated (Park et al. 2006; Ravichandran 2010). The following properties of AgNPs constructed a interest with the components of high sensitivity, biomolecular detection, catalysis, biosensors inhibitory effect, anti-microbial, and medicine are the signifying factor of AgNPs, which made this noble metal nanomaterials to be effective and efficient (El-Chaghaby and Ahmad 2011; Veerasamy et al. 2011). The frequent exploitation of monosodium citrate $\left(\mathrm{C}_{6} \mathrm{H}_{7} \mathrm{NaO}_{7}\right)$ and sodium borohydride (NaBH4) as precursor for NPs' synthesis via physical and chemical routes are often resulted at extremely expensive that generates vulnerability to living and non-living (Mohammad and Fereshteh 2016). The plant-based AgNPs have high volume of research focus on 
the human cancer cell inhibition too. The plant Broussonetia papyrifera is one of the example, where the plant not only economically useful, but also medicinally has high degree of beneficial aspects to human kind in the biomedical field. Hence, the one-pot green synthesis, using plant as biosources for the synthesis of AgNPs, is employed largely (Ahmed et al. 2016a). Among the NPs, AgNPs have high importance towards various property and application such as good conductivity, catalytic, anti-bacterial, anti-fungal, anti-viral etc.... (Ahmad et al. 2003; Klaus-Joerger et al. 2001). The positive side of AgNPs is due to the residue from bioresources that cost effective protects human health and environment, energy efficient, and economical; because of reduced size and shape, the biomedical field is one of the leading field which requires the more production of NPs. For paying attention to future research, it relies on the commercially viable products for better use from nano is the required element (Ahmed et al. 2016b; Caroling et al. 2015) Not only the medicinal plants (Thirumurugan et al. 2010) but fruits also (Ankamwar et al.2005; Jain et al.2009; Annamalai and Nallamuthu 2015) used for production of NPs at large level. In the present study, the attempt is done to synthesis the bioinspired nanoparticles using the fruit extract of Phyllanthus emblica and Coccinia grandis through various characterization techniques and the same has been evaluated against the pathogens tested and for early growth of the seeds, respectively.

\section{Materials and methods}

\section{Materials}

Silver nitrate used as a substrate for the synthesis of AgNPs. $\mathrm{AgNO}_{3}$ was purchased from Himedia laboratories Pvt. Ltd., Mumbai, India. The water has been obtained through glass double distillation.

\section{Collection of plant samples}

The extract of plant sample was collected from the (Thoothukudi) Southern part of Tamilnadu, India.

\section{Preparation of plant extract}

Preparing aqueous extract of Phyllanthus emblica and Coccinia grandis was prepared by taking $20 \mathrm{~g}$ of fleshy layer washed thoroughly with distilled water and dried for 5 days at room temperature. Then, the fleshy layer was powdered and $1 \mathrm{~g}$ of the same powder was taken in a $250 \mathrm{ml}$ Erlenmeyer flask with $100 \mathrm{ml}$ sterile distilled water. The sample was boiled for $5 \mathrm{~min}$ at $70{ }^{\circ} \mathrm{C}$ before finally filtering it. The filtrate thus obtained was stored at $4{ }^{\circ} \mathrm{C}$ and used. Synthesis of AgNPsA $5 \mathrm{ml}$ aliquot of the extract was mixed with $95 \mathrm{ml}$ of aqueous $1 \mathrm{mM} \mathrm{AgNO}$ for reduction of $\mathrm{AgNO}_{3}$ into $\mathrm{Ag}+$ ions and kept at room temperature for up to $24 \mathrm{~h}$. About 10 min after mixing, the color of the solution began changing into reddish brown, indicating the formation of AgNPs. The bioreduce of AgNPs was screened using UV-Vis absorbance (Fig. 1).

\section{UV-visible spectra analysis}

AgNPs were characterized in a Perkin-Elmer UV-Vis spectrophotometer Lambda-19 to know the kinetic behaviour of AgNPs. The scanning range for the sample was $800-200 \mathrm{~nm}$ with a scan speed of $480 \mathrm{~nm} / \mathrm{min}$.

\section{Fourier transform infrared spectroscopy (FTIR)}

Infra red spectroscopy was used to determine and predict possible physicochemical interactions between the components in a formulation using FTIR. The measurements were taken for AgNPs synthesized after $24 \mathrm{~h}$ of reaction and were done using an FTIR SHIMADZU 8400S with a wavelength range of 4000-400 nm, where the samples were incorporated with $\mathrm{KBr}$ pellets to acquire the spectra. The results were compared for shift in functional peaks of critical value.

UV-Vis spectral analysis

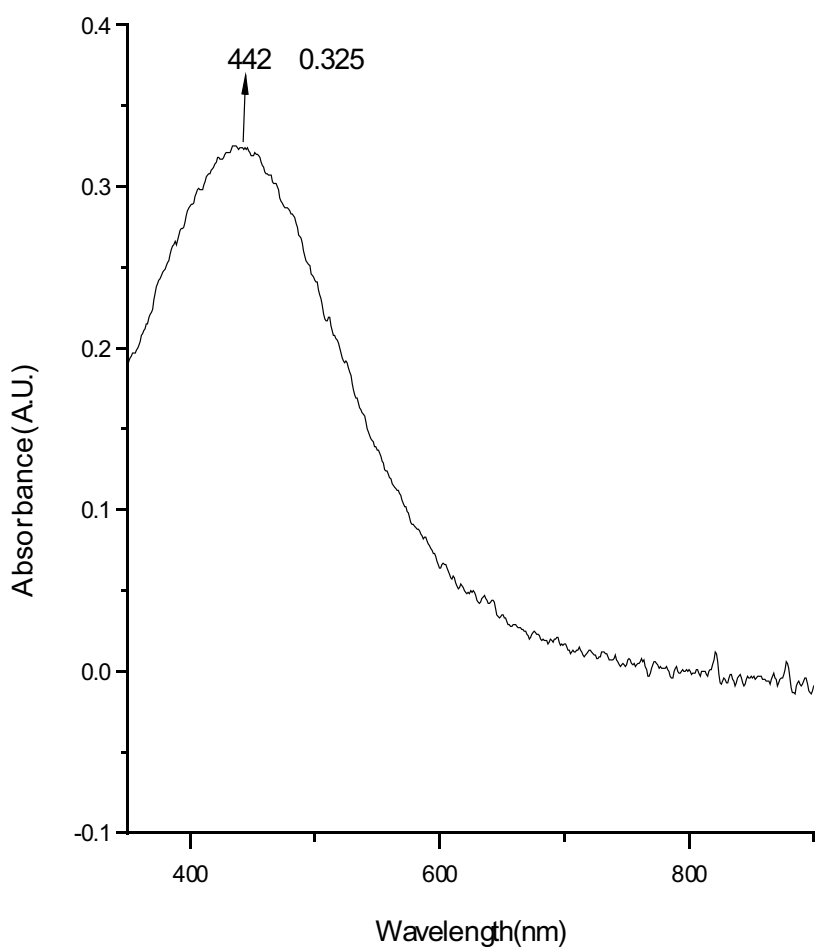

Fig. 1 UV spectroscopic analysis of silver nanoparticles of Coccinia grandis 


\section{XRD analysis}

To determine the XRD patterns of AgNPs, the process were recorded on X-ray diffract meter (expert pan analytical) instrument operating at a voltage of $40 \mathrm{kV}$ and current of $30 \mathrm{~mA}$ with $\mathrm{Cu} \mathrm{K}(\alpha)$ radiation to determine the crystalline phase and material identification. The samples were taken in lids and put under instrument for analysis.

\section{Anti-oxidant activity}

Anti-oxidant activity of $\mathrm{Ag}$ nanoparticles was measured by DPPH method. $1 \mathrm{ml}$ of $0.1 \mathrm{mM}$ DPPH (in ethanol) was added to different concentrations (100, 200, 300, 400, and $500 \mu \mathrm{g} \mathrm{ml}^{-1}$ ) of AgNPs synthesized by fruit extract. The reaction mixture was incubated in the dark for $30 \mathrm{~min}$. The absorbance at $517 \mathrm{~nm}$ was measured. The ascorbic acid $(2 \mathrm{~g}$ in $5 \mathrm{ml}$ water) was used as standard. The lower absorbance of the reaction mixture indicated a higher percentage of scavenging activity. DPPH scavenging activity is calculated using the following equation.

\section{Anti-microbial assay}

The anti-bacterial activities of synthesized silver nanoparticles were carried out by disc-diffusion method (Ghodake et al. 2010; Parashar et al. 2009). The anti-bacterial activity was done on ten-human pathogenic by the standard disc-diffusion method. Nutrient agar medium plates were prepared, sterilized, and solidified. After solidification, bacterial cultures were swabbed on these plates. The discs were soaked in $\mathrm{AgNO}_{3}$ solution and solution containing AgNPs of each type separately. The sterile discs were dipped in AgNPs' solution $(10 \mathrm{mg} / \mathrm{ml})$ and placed in the nutrient agar plate and kept for incubation at $37^{\circ} \mathrm{C}$ for $24 \mathrm{~h}$. The inhibition was measured and compared with the standard antibiotic disc and silver nitrate solution and AgNPs. The experiments repeated thrice values of zone diameter were presented effect of biosynthesized silver nanoparticles on seed germination (Saminathan 2015). The seeds were purchased from the local market (Gandhi market), Tiruchirappalli, TN. Seeds were surface sterilized with $1 \%$ mercuric chloride solution for $1 \mathrm{~min}$ and rinsed several time in sterile distilled water. The following analyses are experimented with five different varieties of seeds.

\section{Percentage of seed germination}

Seed germination $(\%)=($ Number of germinated seeds $/$ Number of total seeds) $\times 100$.

\section{Root and shoot length}

Root length was taken from the point below the hypocotyls to the end of the tip of the root. Shoot length was measured from the base of the root-hypocotyl transmission zone up to the base of the cotyledons. The root and shoot length was measured with the help of a scale.

\section{Fresh and dry weight}

The fresh weight of root and shoot of seedlings was determined by weigh the root and shoot separately on electric balance. After the fresh weight taken, then the seedlings were kept in a hot air oven at $80^{\circ} \mathrm{C}$ for $48 \mathrm{~h}$, and then, the weight of dry matter was recorded.

\section{Determination of relative water content (RWC)}

RWC was calculated using the method of Barrs and Weatherly (1962). The seedlings were weighed and then dipped in distilled water for $4 \mathrm{~h}$. The seedlings were then blotted dry and weighed prior to oven drying at $80^{\circ} \mathrm{C}$ for $24 \mathrm{~h}$ :

RWC $=$ Fresh weight Dry weight/Turgid weight Dry weight $\times 100$.

\section{Results and discussion}

\section{UV-visible spectra analysis}

AgNPs were characterized by UV-Vis spectroscopy, a prominence technique for the structural categorization NPs (Khanra et al. 2016). In general, the alteration AgNPs exhibit the color change from yellowish to reddish brown rues to the excitation of surface Plasmon vibration of the colloidal AgNPs. The noticeable observations that make the solution to have no more silver mirror like solution and finally that has been turned to brownish red. Thus, AgNPs are known to exhibit an intense surface Plasmon absorption band in the range of (400-500 nm) (Jayandran et al. 2015). However, AgNPs of Coccinia grandis show surface Plasmon resonance at $442 \mathrm{~nm}$ and AgNPs of Phyllanthus emblica illustrated peak at $443 \mathrm{~nm}$ (Table 1; Figs. 1, 2). In addition, the frequency and width of the Plasmon resonance are due to the shape and size of AgNPs. These particular spectra are

Table 1 Comparative study of UV spectroscopic analysis (reduction in the spectral Peak)

\begin{tabular}{|c|c|c|c|}
\hline $\begin{array}{l}\text { Absorption peak of } \\
\mathrm{AgNO}_{3}(\mathrm{~nm})\end{array}$ & Species name & $\begin{array}{l}\text { Abs } \\
\text { peak }\end{array}$ & \\
\hline 196 & Coccinia grandis & 442 & 0.325 \\
\hline 196 & Phyllanthus emblica & 423 & 0.446 \\
\hline
\end{tabular}




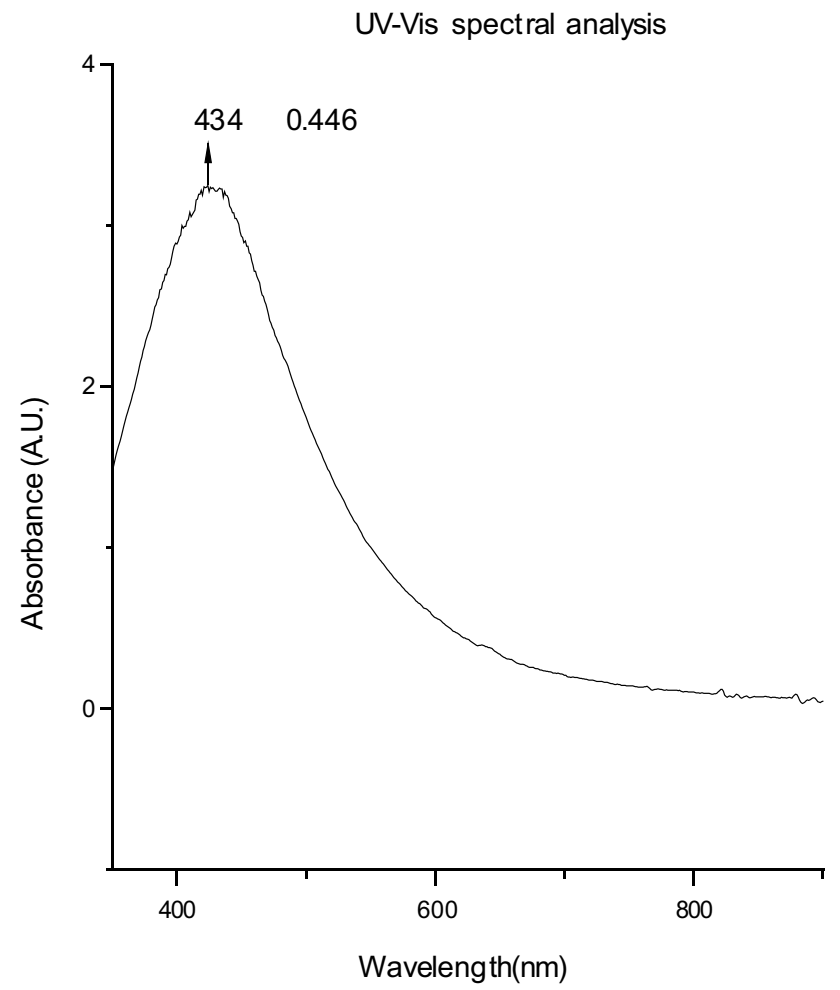

Fig. 2 UV spectroscopic analysis of silver nanoparticles of Phyllanthus emblica

used to examine the size and of NPs to be controlled and confined in aqueous solution.

\section{Fourier transform infrared spectroscopy (FTIR)}

The FTIR characterization used foremost for locating the biomolecules that holds accountable for the process of reduction and stabilization of AgNPs. Hence, the absorbance bands were originated in the region $400-4000 \mathrm{~cm}^{-1}$. The first band originates from AgNPs—-egend stretching vibration that appears due to interaction of biomolecules with AgNPs. The absorbance bands are observed in the region of $400-4000 \mathrm{~cm}^{-1}$. In AgNPs of Coccinia grandis, the bands are corresponding to $3410.16,2927.56,2854.58,2076.56$, $1738.18,1640.02,1458.25,1240.93,1156.47,1085.77$, and $712.24 \mathrm{~cm}^{-1}$. These absorbance bands are known to be associated with the stretching vibrations (Tables 2, 3; Figs. 3, 4). The bands at $3410.16-2854.58 \mathrm{~cm}^{-1}$ correspond to $\mathrm{O}-\mathrm{H}$ stretch and $\mathrm{CH}_{3}, \mathrm{CH}_{2}$, and $\mathrm{CH}$ vibrations of alcohol, phenol, and alkanes. The peak at $2076.56-1458.25 \mathrm{~cm}^{-1}$ indicates $\mathrm{C}-\mathrm{H}$ - and $\mathrm{Si}-\mathrm{OR}$-stretching vibrations of alkene and amines. The peak at $1240.93 \mathrm{~cm}^{-1}$ represents the $\mathrm{Si}-\mathrm{OR}$ bending of silicon, alcohols, carboxylic acids, esters, and ethers as well. The biomolecules present in AgNPs of Phyllanthus emblica were indentified from FTIR analysis. Hence, this analysis was used to find the chemical bonds present in the reaction medium. This spectrum showed the absorption peaks at $3433.97,2074.64,1637.45,1461.98,1410.98$, $1153.73,1078.06$, and 683.94 . The strong absorbance band at $3433.97 \mathrm{~cm}^{-1}$ was associated with the stretch of functional group O-H stretch of alcohol/phenol. And also, a strong peak at 1637.45 corresponds to $\mathrm{N}-\mathrm{H}$ bond of amines, which is said to the responsible feature for the synthesis of AgNPs.

\section{Scanning electron microscopy (SEM) analysis}

The AgNPs morphology and topography were the investigational part using SEM. Thus, the agglomerated AgNPs are spherical shape (Ankanna et al. 2010). AgNPs synthesized via Coccinia grandis and Phyllanthus emblica embraces many shapes, which are clearly observed. These two SEM images also show the aggregation of AgNPs. The topography of AgNPs was mostly spherical in shape (Janani et al. 2014). The accessibility of biomolecules in these plants has consequence in the synthesis of spherical AgNPs (Figs. 5
Table 2 FT-IR peak value and its functional groups of fruit extracts of AgNPs of Coccinia grandis

\begin{tabular}{lclll}
\hline $\begin{array}{l}\text { Composition } \mathrm{AgNO}_{3} \text { :Extract } \\
\text { 95: } 5(\mathrm{ml})\end{array}$ & Frequency range & Bond & Compound type \\
\hline 24 h-Time duration & 3410.16 & $3200-3550$ & $\mathrm{O}-\mathrm{H}$ stretch & Alcohol/Phenol \\
& 2927.56 & $2850-3000$ & $\mathrm{CH}_{3}, \mathrm{CH}_{2} \& \mathrm{CH}$ stretch & AlKanes \\
& 2854.58 & $2850-3000$ & $\mathrm{CH}_{3}, \mathrm{CH}_{2} \& \mathrm{CH}$ stretch & AlKanes \\
& 2076.56 & $1000-1100$ & $\mathrm{Si}-\mathrm{OR}$ & Silicon \\
1738.18 & $1000-1100$ & $\mathrm{Si}-\mathrm{OR}$ & Silicon \\
1640.02 & $1580-1650$ & $\mathrm{~N}-\mathrm{H}$ bond & Amines \\
1458.25 & $1350-1470$ & $\mathrm{CH}_{2} \& \mathrm{CH}_{3}$ deformation & Alkanes \\
& 1240.93 & $1000-1100$ & $\mathrm{Si}-\mathrm{OR}$ & Silicon \\
& $1000-1400$ & $\mathrm{C}-\mathrm{F}$ stretch & Halogen \\
& 1156.47 & $1000-1400$ & $\mathrm{C}-\mathrm{F}$ stretch & Halogen \\
1085.77 & $1000-1100$ & $\mathrm{Si}-\mathrm{OR}$ & Silicon \\
712.24 & $600-800$ & $\mathrm{C}-\mathrm{d}$ stretch & Halogen \\
\hline
\end{tabular}


Table 3 FT-IR peak value and its functional groups of fruit extracts of AgNPs of Phyllanthus emblica

\begin{tabular}{|c|c|c|c|c|}
\hline \multirow{2}{*}{$\frac{\text { Composition } \mathrm{AgNO}_{3} \text { Extract 95: } 5(\mathrm{ml})}{24 \text { h-Time duration }}$} & \multicolumn{2}{|c|}{ Frequency range } & \multirow{2}{*}{$\frac{\text { Bond }}{\mathrm{O}-\mathrm{H} \text { stretch }}$} & \multirow{2}{*}{$\begin{array}{l}\text { Compound } \\
\text { Alcohol/Phenol }\end{array}$} \\
\hline & 3433.97 & $3200-3550$ & & \\
\hline & 2074.64 & $1000-11,000$ & Si-OR & Silicon \\
\hline & 1637.45 & $1580-1650$ & $\mathrm{~N}-\mathrm{H}$ bond & Amines \\
\hline & 1461.98 & $1350-1470$ & $\mathrm{CH} 2 \& \mathrm{CH} 3$ deformation & Alkenes \\
\hline & 1410.98 & $1350-1470$ & $\mathrm{CH} 2$ \& $\mathrm{CH} 3$ deformation & Alkenes \\
\hline & 1153.73 & $1000-1400$ & $\mathrm{C}-\mathrm{F}$ stretch & Halogen \\
\hline & 1078.06 & $1000-1400$ & C-F stretch & Halogen \\
\hline & 683.94 & $600-800$ & C-d stretch & Halogen \\
\hline
\end{tabular}

ACIC

St.Joseph's College ( Autonomous)

Trichy-2

Spectrum Name: IR-Bot-B.sp

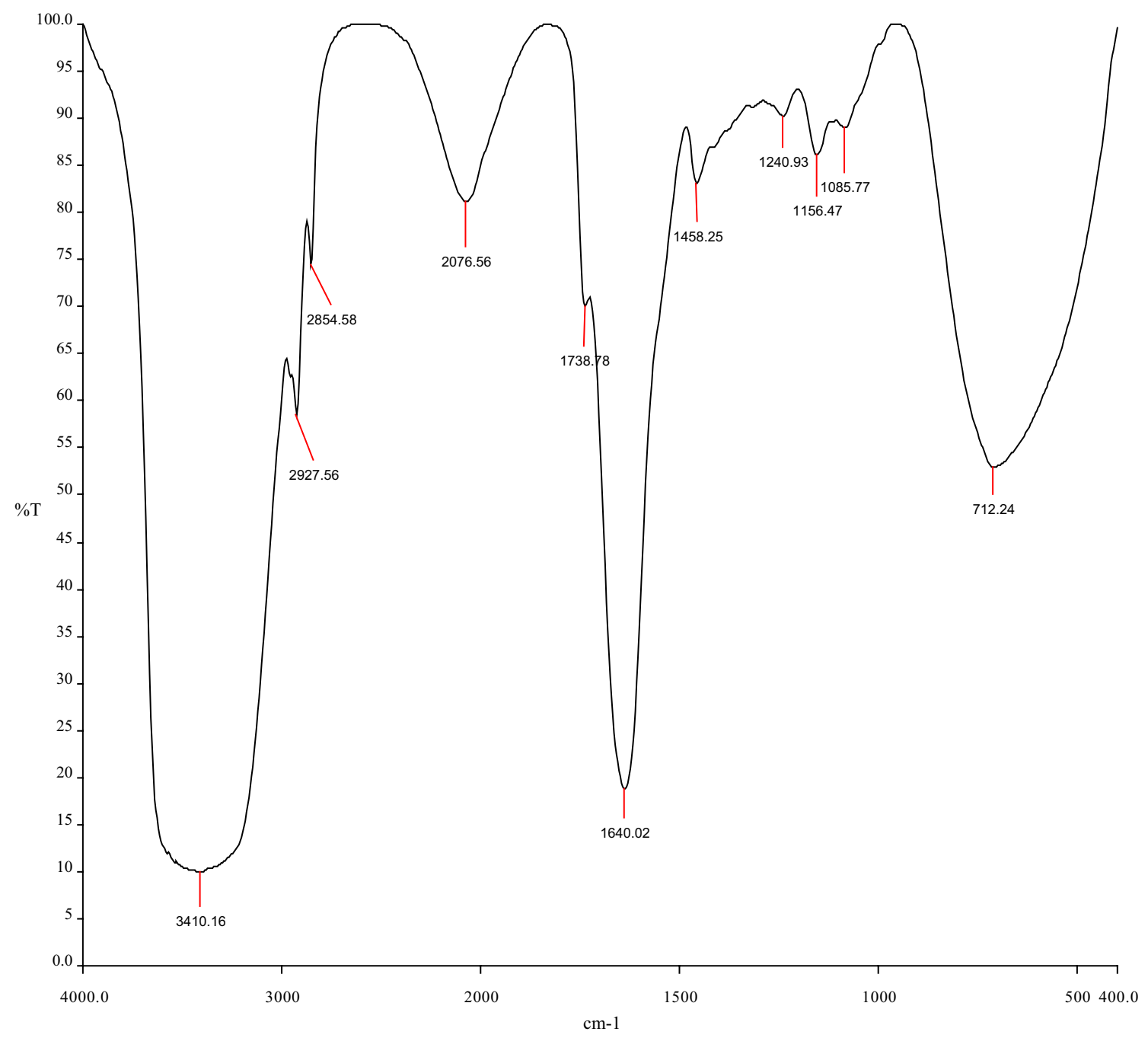

Fig. 3 FT-IR peak value AgNPs of Coccinia grandis 
Spectrum Name: IR-Bot-D.sp

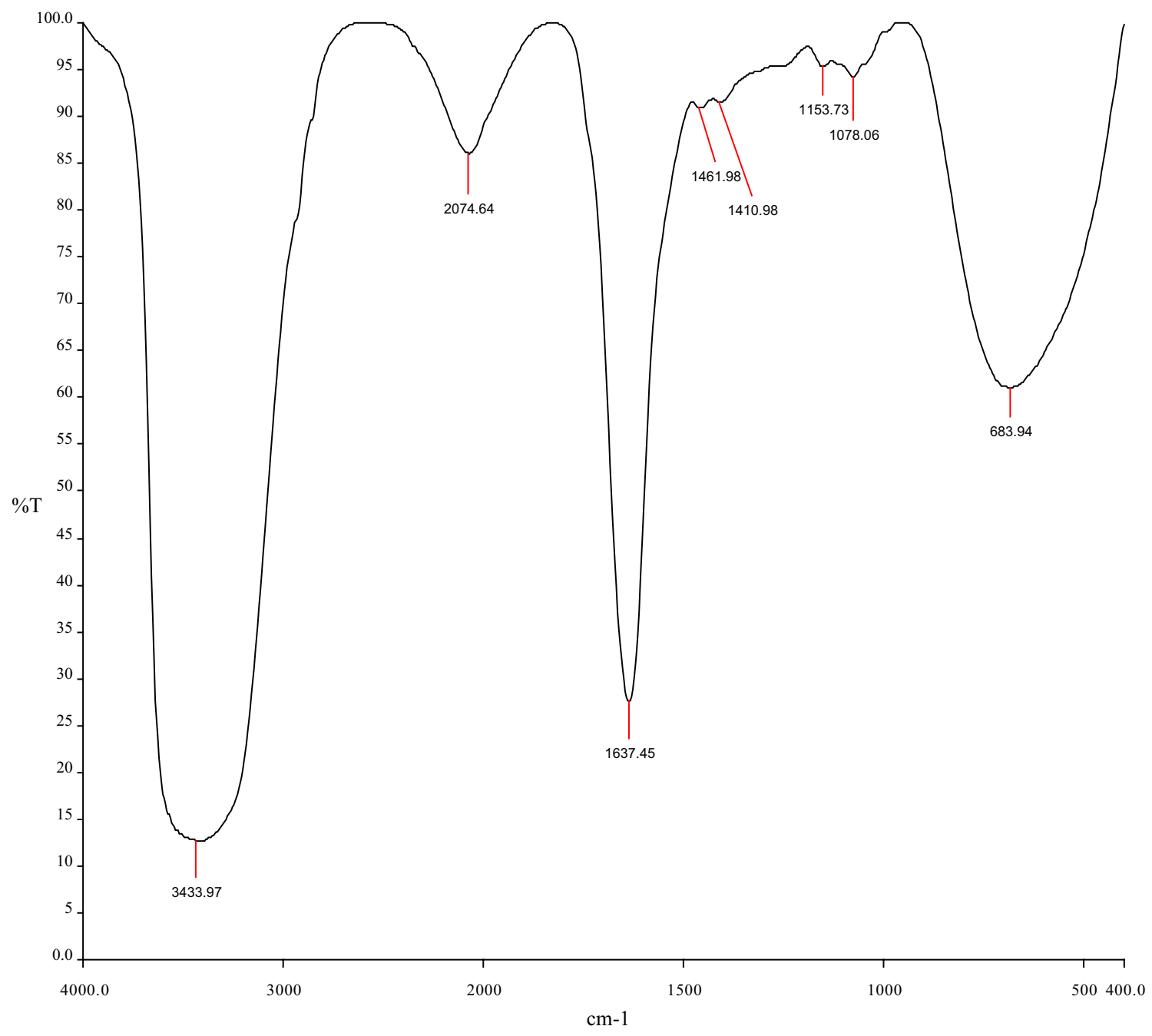

Fig. 4 FT-IR peak value AgNPs of Phyllanthus emblica

and 6). In this parameter, AgNPs of $C$. grandis showed 22, 26, $14 \mu \mathrm{m}$ and AgNPs of P. emblica give an idea about 23, 44 and $98 \mu \mathrm{m}$, respectively. The SEM images of AgNPs had illustrated that most of the particles are polymorphic morphology due to moderately dispersed and slightly agglomerated in nature.

\section{XRD analysis of AgNPs}

The biosynthesized AgNPs using Coccinia grandis and Phyllanthus emblica fruit extract was exhibited and confirmed by the characteristic peaks examined in the XRD image.
AgNPs of $C$. grandis include Braggs reflections clearly showing the presence of (111), (200), (220), (311), (222), and (420) sets of lattice planes and they can be indexed as face-centered-cubic (FCC) structure of AgNPs. The XRD pattern thus clearly match ups that AgNPs are crystalline in nature (Sulaiman et al. 2013). In addition, AgNPs of Phyllanthus emblica the strong peaks were observed at $2 \theta$ values at $38.09^{\circ}, 44.15^{\circ}, 64.67^{\circ}$, and $77.54^{\circ}$, corresponding to (111), (200), (220), and (311) Bragg's reflection based on the face-centered-cubic (fcc) crystal structure of AgNPs. The XRD analysis shows three distinct diffraction peaks at 38.3, 44.2 , and 64.0 and can be indexed $2 \theta$ values of (111), (200), 
Fig. 5 SEM image-AgNPs of Coccinia grandis
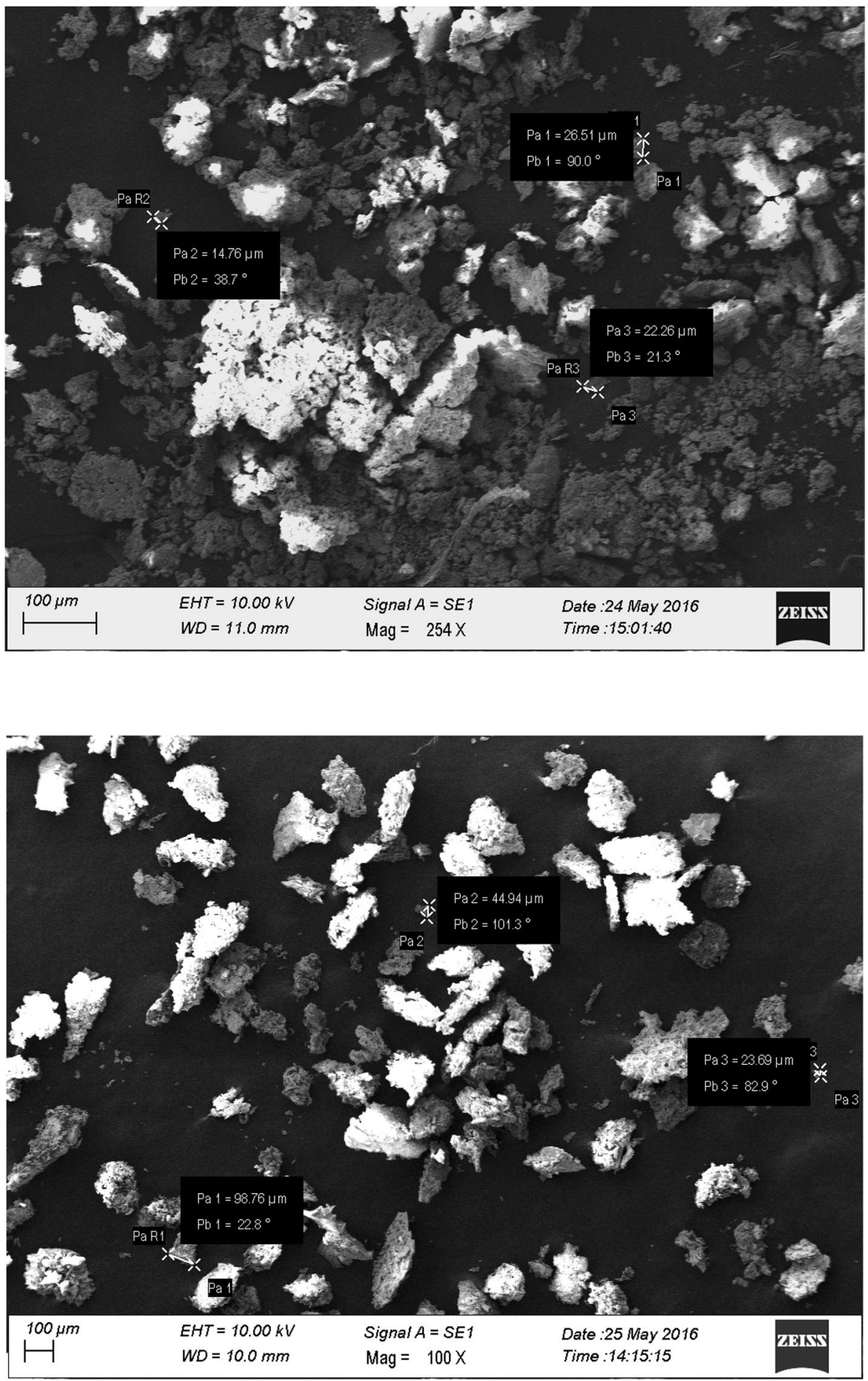

Fig. 6 SEM image indicating the size AgNPs of Phyllanthus emblica and (220) crystalline planes of cubic AgNPs. The middling grain size of AgNPs outlined in the bioreduction procedure is established using Scherr's formula, $d=\left(0.9 \lambda \times 180^{\circ}\right) / \beta$ $\cos \theta \pi$. The XRD pattern is thus comprehensible that AgNPs are crystalline in nature (El-Rafie and Hamed 2014). The Bragg peaks symbolize of FCC AgNPs, and supplementary fact that yet some unassigned peaks were also observed recommending that the crystallization of bioorganic phase occurred on the surface of the NPs (Figs. 7, 8).

\section{Anti-oxidant assay}

The DPPH experimentation illustrates the synthesized AgNPs posses' significant anti-oxidant prospective. This

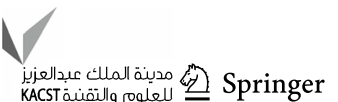




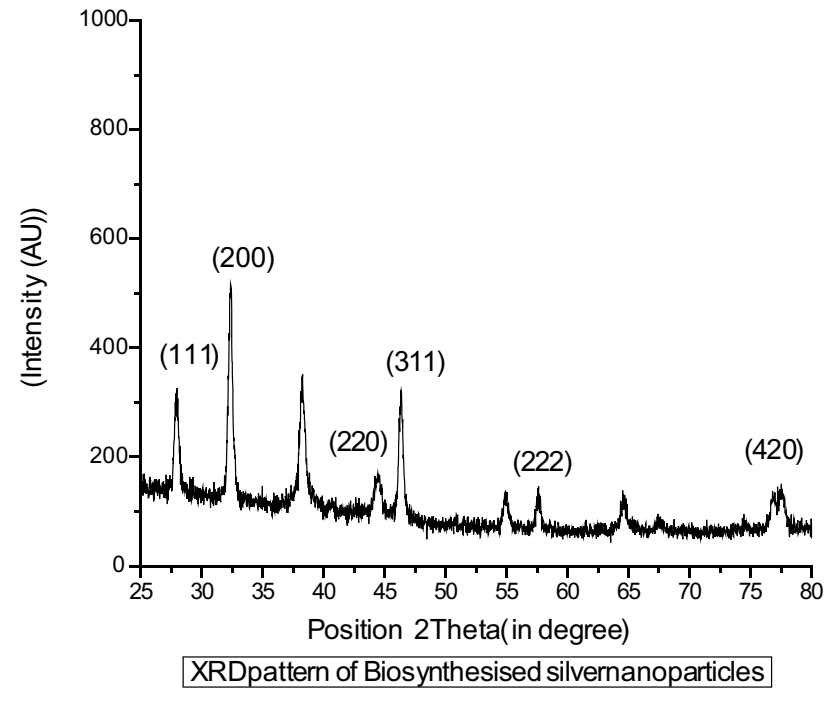

Fig. 7 XRD spectrum of AgNPs from Coccinia grandis

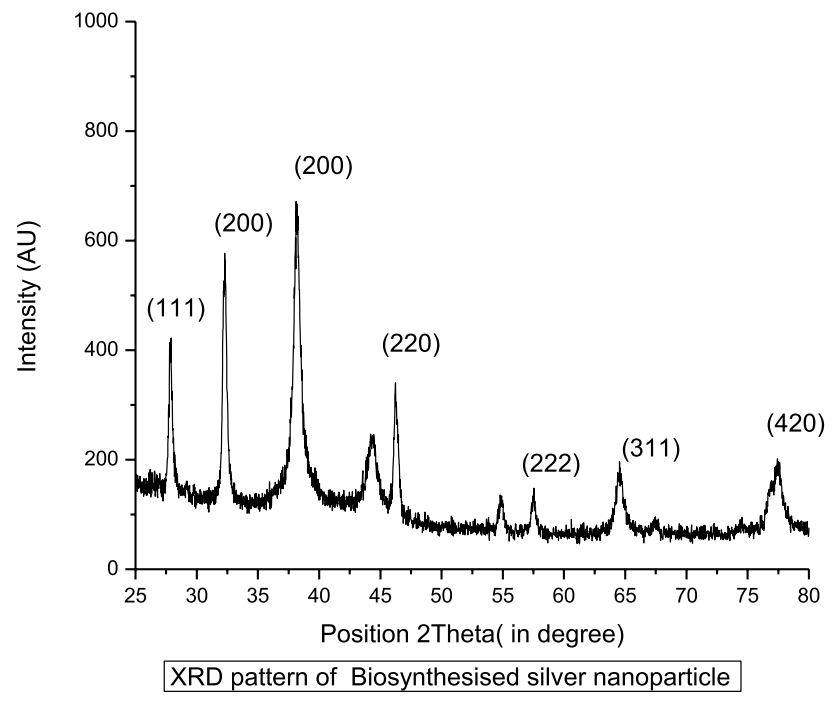

Fig. 8 XRD spectrum of AgNPs from Phyllanthus emblica happens due to diminution by accepting the hydrogen or electron. The reducing ability of AgNPs was measured spectrophotometrically with strong absorption band at $517 \mathrm{~nm}$ by changing the DPPH color from purple to yellow (Kumar et al. 2015). Inhibition was found to be high in AgNPs because of the actuality that Ag acts as a good anti-oxidant can easily lose electrons. The DPPH assay shows effective free radical inhibition by AgNPs (Figs. 9, 10). The electron in the substance becomes paired in the presence of a free radical scavenger; the absorption become vanish and leads to consequential decolorization (Devika et al. 2012).

AgNPs of the two fruit extract have compelling the free radical scavenger when we compare to standard ascorbic acid. An anti-oxidant effort is in stopping the oxidation by neutralizing the free radicals produced. To deactivate the free radicals, the anti-oxidants itself go through oxidation (Harajyoti and Ahmed 2011; Kranner and Colville 2011). The movement and stability of AgNPs are affected during the oxidation process and also they are oxidized in the presence of the air. This anti-oxidant activity may be due to the capping constituents present in plant extract known secondary metabolites and present on the metal surface. The size of the NPs determines the final product that corresponds to its applications in various fields. Moreover, the FESEM spectroscopy provides much better image or topographic aspects of the obtained NPs. Based on the size provided by the spectroscopy, one can design a that can be a to various other drug that are available commonly in the market.

\section{Anti-microbial assay}

There are numerous aspects responsible for the anti-bacterial activity of AgNPs. The main mechanism by which these NPs demonstrate anti-bacterial activity might be via oxidative stress produced by reactive oxygen species (ROS). This element can cause damage to proteins and DNA in bacteria. AgNPs could be the resource that created ROS leading to the inhibition of E. coli. A parallel process was depicted
Fig. 9 Effect of various concentrations of AgNPs on antioxidant activities of Coccinia grandis
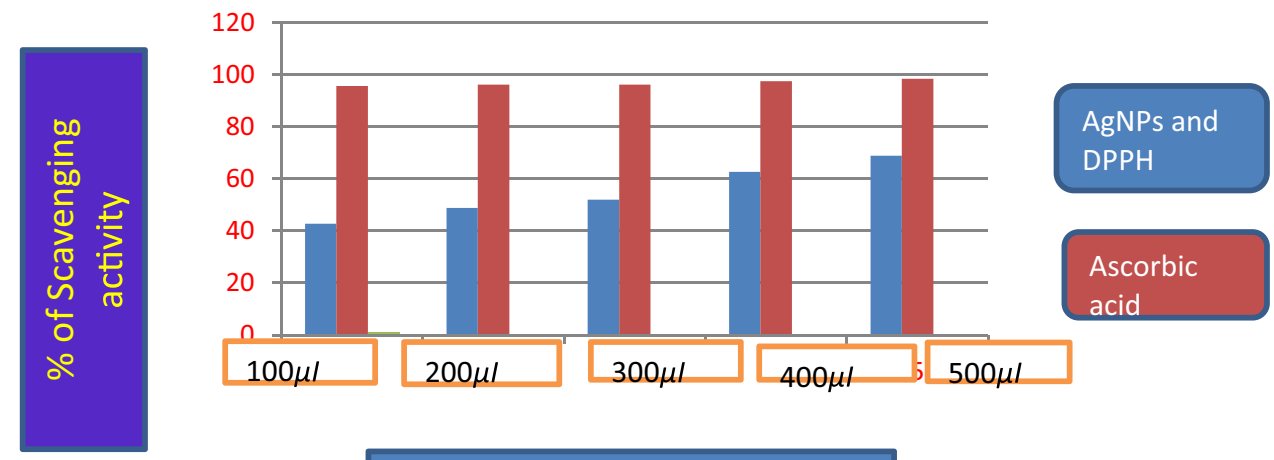

Concentration $(\mu /)$ 
by authors in whom zero valent silver $\left(\mathrm{Ag}_{0}\right)$ reacted with oxygen to create hydrogen peroxide $\left(\mathrm{H}_{2} \mathrm{O}_{2}\right)$ which smash up the bacterial cell wall (Pavani et al. 2014). The antimicrobial activity of AgNPs' bacteria was dependent on the concentration of AgNPs and was closely associated with the lowest point in the cell wall of bacteria (Tables 4, 5). A number of theories for anti-microbial actions of colloidal silver solution have been proposed. For example, alteration of permeability of cell membrane release of lipopolysaccharides and membrane proteins generation of free radicals
Fig. 10 Effect of various concentrations of AgNPs on antioxidant activities of Phyllanthus emblica
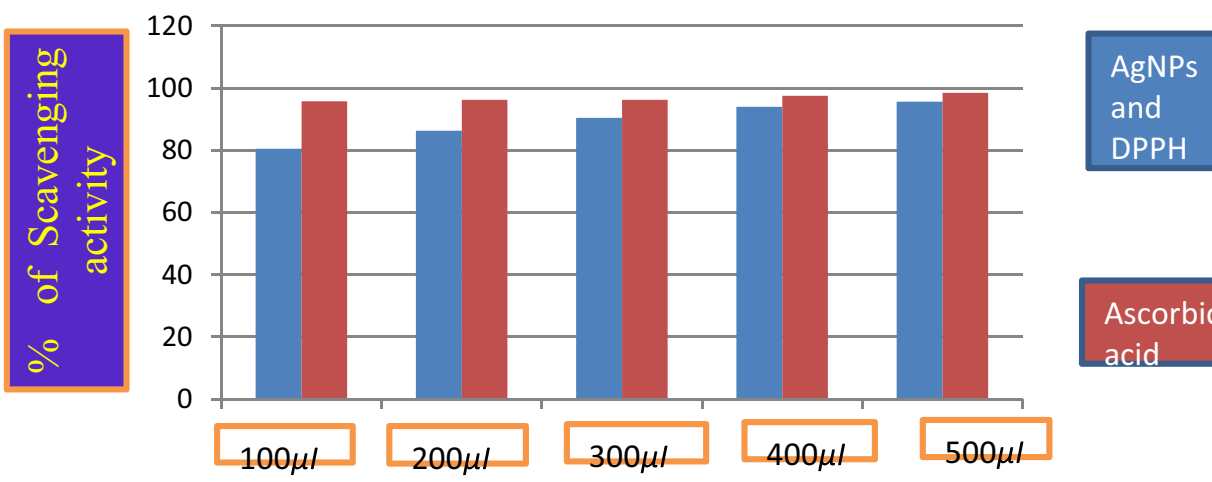

and

$\mathrm{DPPH}$

Ascorbic

acid
Table 4 Anti-bacterial activity of silver nanoparticles from Coccinia grandis
Table 5 Anti-bacterial activity of silver nanoparticles from Phyllanthus emblica

\begin{tabular}{llll}
\hline Name of the bacteria & $\begin{array}{l}\text { Silver nanoparticles } \\
{[\text { AgNPs] }(\mathrm{mm})}\end{array}$ & $\begin{array}{l}\text { Antibiotic [Streptomycin] } \\
(\mathrm{mm})\end{array}$ & $\begin{array}{l}\text { Silver nitrate } \\
{\left[\mathrm{AgNO}_{3}\right](\mathrm{mm})}\end{array}$ \\
\hline Staphylococcus aureus & 11 & 14 & 10 \\
Bacillus subtilis & 12 & 23 & 11 \\
Escherichia coli & 11 & 20 & 10 \\
Serratia marcescens & 13 & 24 & 12 \\
Vibrio cholerae & 15 & 24 & 12 \\
Shigella sannei & 11 & 24 & 10 \\
Klebsiella pneumonia & 11 & 21 & 10 \\
Proteus vulgaris & 13 & 17 & 10 \\
Salmonella typhi & 11 & 24 & 10 \\
Proteus mirabilis & 12 & 20 & 10 \\
\hline
\end{tabular}

Comparative study of zone of clearance between $\mathrm{AgNPs}, \mathrm{AgNO}_{3}$, and antibiotic against some human pathogenic bacteria (zone of inhibition measured in $\mathrm{mm}$ )

\begin{tabular}{llll}
\hline Name of the Bacteria & $\begin{array}{l}\text { Silver nanoparticles } \\
{[\mathrm{AgNPs}](\mathrm{mm})}\end{array}$ & $\begin{array}{l}\text { Antibiotic [Streptomycin] } \\
(\mathrm{mm})\end{array}$ & $\begin{array}{l}\text { Silver nitrate } \\
{\left[\mathrm{AgNO}_{3}\right](\mathrm{mm})}\end{array}$ \\
\hline Staphylococcus aureus & 12 & 19 & 10 \\
Bacillus subtilis & 11 & 19 & 10 \\
Escherichia coli & 11 & 20 & 10 \\
Serratia marcescens & 12 & 17 & 11 \\
Vibrio cholerae & 13 & 27 & 10 \\
Shigella sannei & 11 & 21 & 10 \\
Klebsiella pneumonia & 10 & 22 & 11 \\
Proteus vulgaris & 12 & 18 & 10 \\
Salmonella typhi & 12 & 20 & 11 \\
Proteus mirabilis & 12 & 26 & 11 \\
\hline
\end{tabular}


responsible for the damage of membrane and dissipation of the proton motive force resulting in the collapse of the membrane potential, however; the exact mechanism has not been fully deciphered.

AgNPs reported in the present study may be ascribed to the mechanism described above, but it still remains to elucidate the exact consequence of AgNPs on cellular metabolism like DNA, RNA, and protein synthesis (Figs. 11, 12, 13, 14) AgNPs of these two plant sources shows the maximum zone of inhibition in Vibrio cholera. In addition, above results are corresponding to antiracial activity and similar values are found. The strongest anti-bacterial effect was on $V$. cholerae at $28 \mathrm{~mm}$ due to their large surface area-to-volume ratio. The potential reason for the anti-bacterial activity of silver is that AgNPs may attach to the surface of the cell membrane disturbing permeability and respiration functions of the cell. Smaller AgNPs having the large surface area available for interaction would give more anti-bacterial activity. Hence, AgNPs are being considered as magnificent agent to fight against the resilient pathogens. This research predicts that $V$. cholerae the organism has demonstrated the maximum zone of inhibition with 15 and $13 \mathrm{~mm}$, respectively. This is a true evident that biologically synthesized AgNPs are more biocompatible and a way for designing a new drugs that act against multi-drug-resistant pathogen. The spherical-shaped AgNPs often gives better results when the synthesized via plant extracts.

\section{Seed germination assay}

The adverse effect due to size and shape of AgNPs was evaluated using seed germination test using Cicer arietinum, Pisum sativum, Lablab purpureus seeds which were exposed to different concentrations of AgNPs $(\mu \mathrm{g} / \mathrm{ml})$. AgNPs confirmed adverse effect on seed germinations, root, and shoot growth on these three seed variety when they were soaked and incubated at different concentrations of AgNPs. The NPs on seeds proves for the biochemical, physiology, and molecular inference and their significance in the development of seeds. AgNPs generally affect seed variability and germination at different concentrations when applied in the micro-to-milli-molar range. C. arietinum seeds grown-up in zinc NPs confirmed the increase in germination: shoot length, root length, fresh weight, and dry weight, whereas seeds grown in zinc metal alone diminish the growth. The verdicts recommend that bioengineered zinc NPs be evidence for constructive outcome on seedlings growth (Pavani et al. 2014). In addition, the seed dormancy and early seedling growth can be achieved from using AgNPs, where it is considered as on the positive application in the field of agriculture and in present study also reveals that growth rate and early development of seed are found good in AgNPinduced seed; whereas compared to another counterpart, it is said to be very less and seems negative with contamination found in the process (Table 6, 7; Figs. 15, 16). The seed dormancy with higher volume always leads to poor growth and germination of seeds. To get the better results, the NPs provide better solution to formers, where the NPs become an option to eradicate long seed dormancy and to initiate the growth. The shape and size of AgNPs can be a better choice and, moreover, having the surface volume ratio; one can determine the very fact that the spherical shape AgNPs that have been determined from SEM image would give products towards its application.

\section{Conclusion}

The advancement of science and technology has created the dire need in adapting the new science (Nanotechnology), where AgNPs' synthesis, manipulation, and its application become part of human need. We presented the biosynthesis
Fig. 11 Anti-bacterial activity of AgNPs on fruit extract of Coccinia grandis against human pathogenic bacteria using discdiffusion method

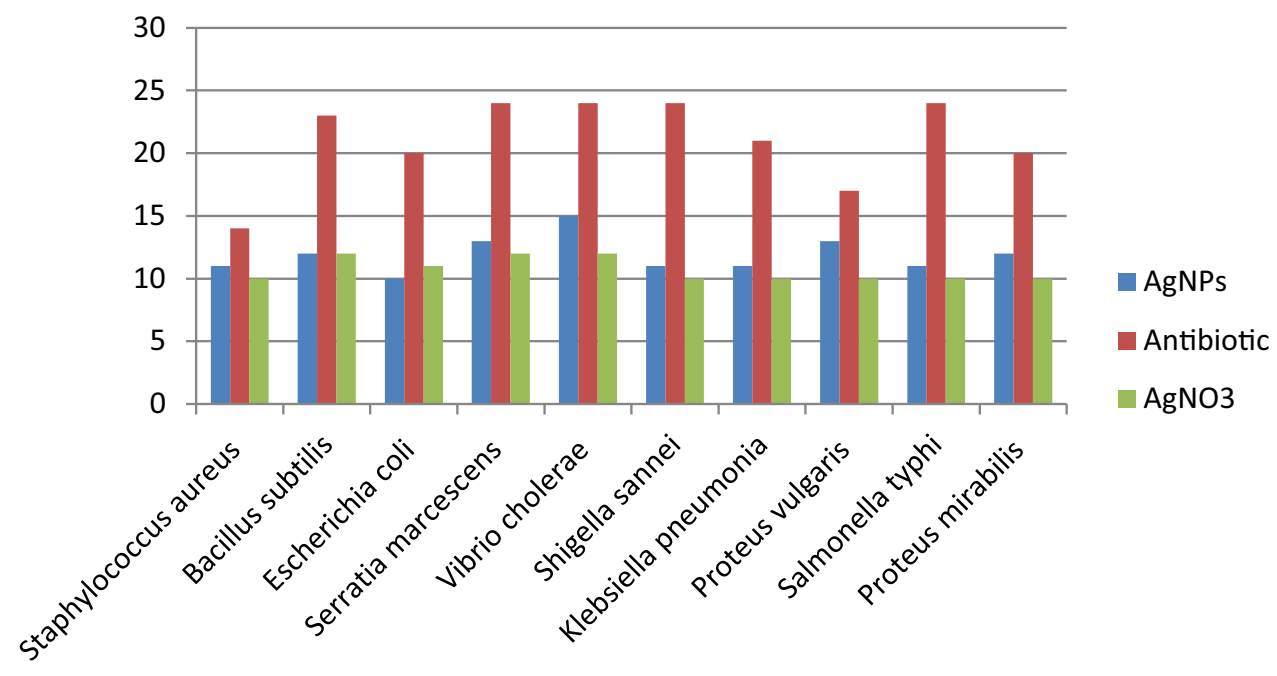




\section{PLATE - 2 (A)}

\section{Antimicrobial activity of Coccina grandis}
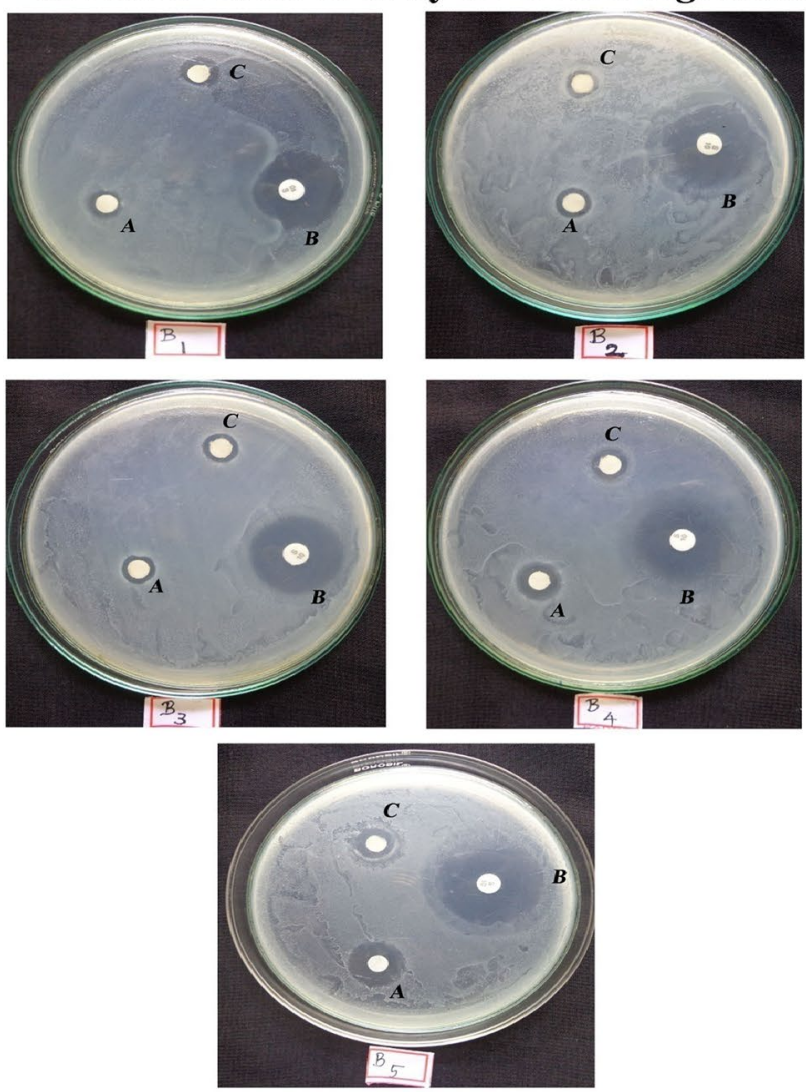

B1-Staphylococcus aureus B2 - Bacillus subtilis

A-AgNPs

B3 - Escherichia coli

B4 - Serratia marcescens

B-Streptomycin

$\mathrm{C}-\mathrm{AgNO}_{3}$
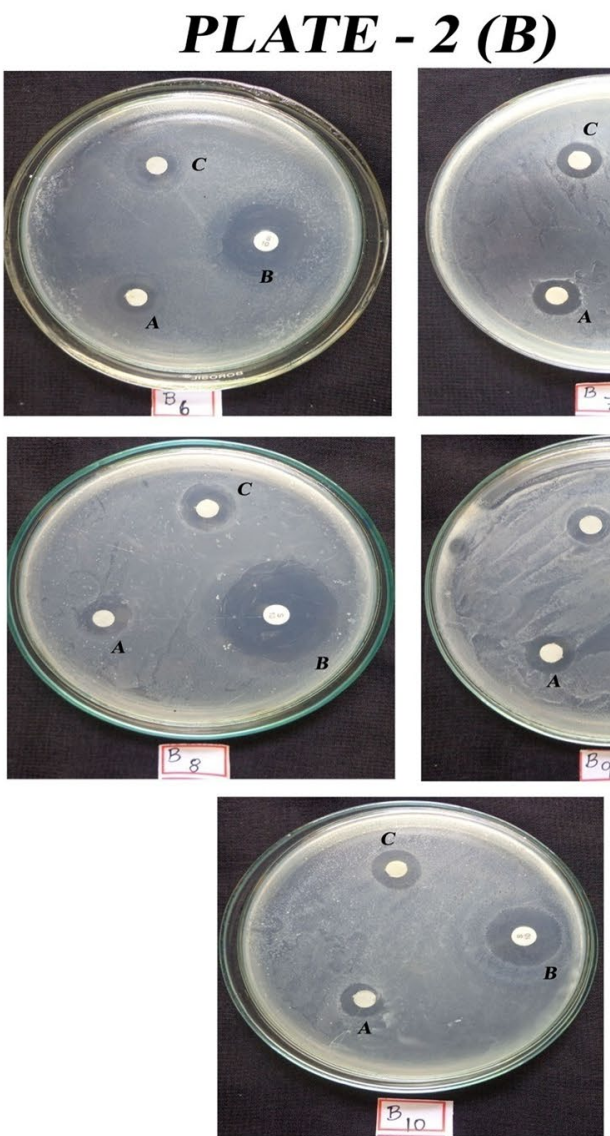

B6-Shigella sannei

B7-Klebsiella pneumonia

B8 - Proteus vulgaris

B9 - Salmonella typhi

B10 - Proteus vuloaris
$\boldsymbol{A}-\boldsymbol{A g N P S}$

B - Streptomycin

$\mathrm{C}-\mathrm{AgNO}_{3}$

B5 - Vibrio cholerae

Fig. 12 Culture plate showing anti-microbial activity of silver nanoparticles: Coccinia grandis

Fig. 13 Anti-bacterial activity of AgNPs on fruit extract of Phyllanthus emblica against human pathogenic bacteria using disc-diffusion method
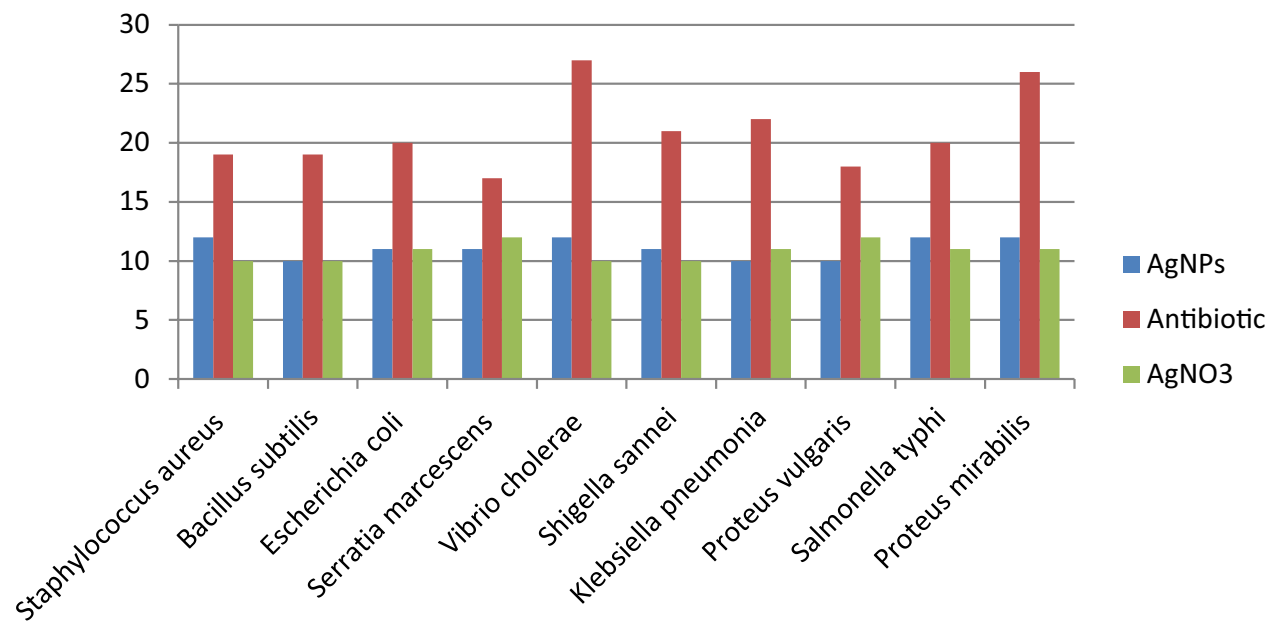


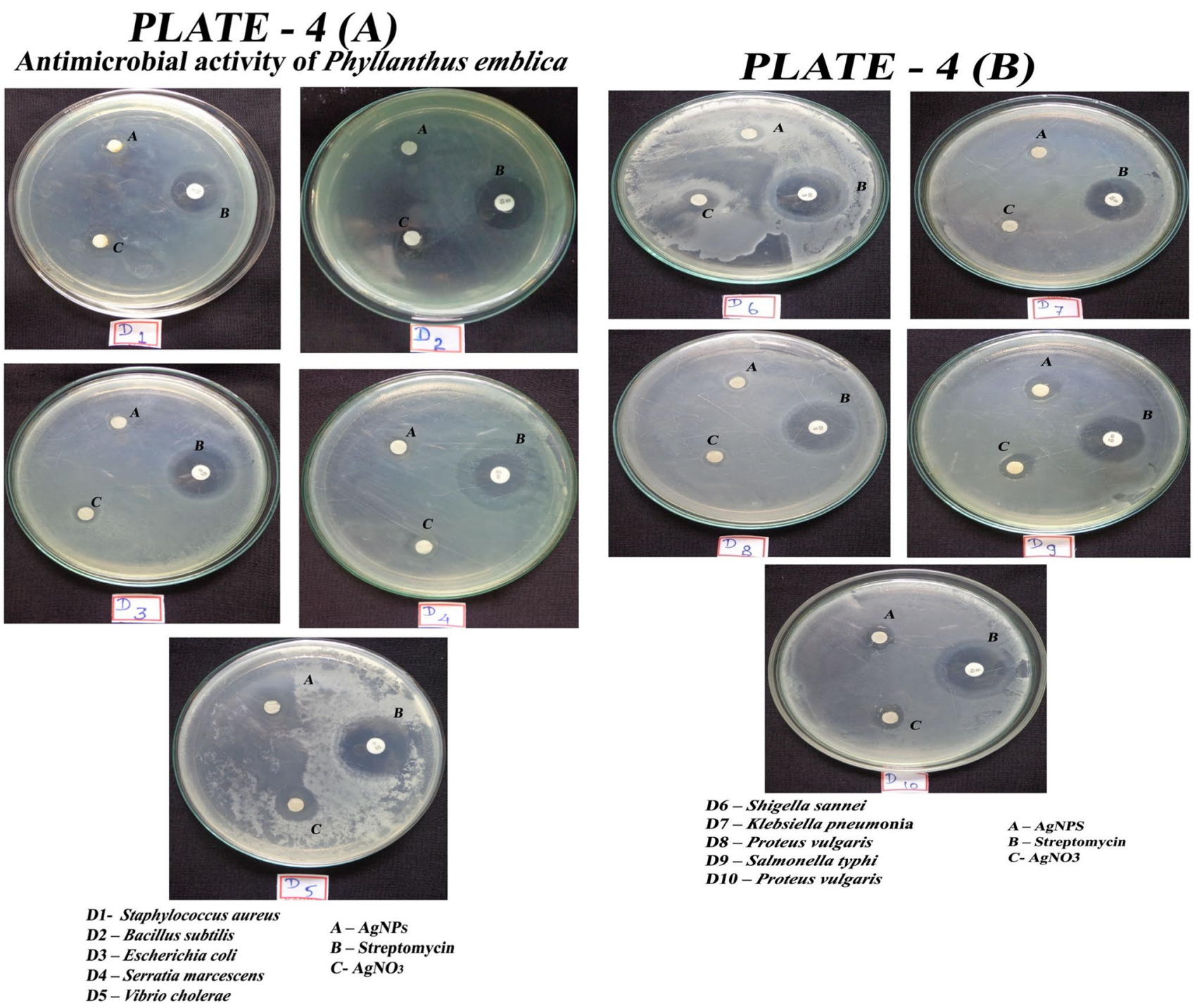

Fig. 14 Image of culture plate showing anti-microbial activity of silver nanoparticles: Phyllanthus emblica

Table 6 Seed germination assay on the Coccinia grandis

\begin{tabular}{|c|c|c|c|c|c|c|}
\hline \multirow{2}{*}{\multicolumn{2}{|c|}{$\begin{array}{l}\text { Seed germina- } \\
\text { tion }(\%)\end{array}$}} & \multicolumn{2}{|c|}{ Seedling growth (cms) } & \multirow[t]{2}{*}{ Fresh weight (gms) } & \multirow[t]{2}{*}{ Dry weight (gms) } & \multirow{2}{*}{$\begin{array}{l}\text { Relative } \\
\text { water con- } \\
\text { tent }(\%)\end{array}$} \\
\hline & & Root length & Shoot length & & & \\
\hline \multicolumn{7}{|c|}{ Cicer arietinum } \\
\hline Control & 100 & $0.35 \pm 1.5$ & $0.75 \pm 3.3$ & $107.6 \pm 517$ & $77.4 \pm 293$ & 85 \\
\hline AgNPs & 100 & $0.27 \pm 1.7$ & $0.57 \pm 43$ & $50.5 \pm 669$ & $32.5 \pm 343$ & 89 \\
\hline \multicolumn{7}{|c|}{ Pisum sativum } \\
\hline Control & 40 & $0.27 \pm 1.3$ & $0.79 \pm 2.5$ & $61.4 \pm 597.8$ & $48.8 \pm 311$ & 70 \\
\hline AgNPs & 100 & $0.41 \pm 1.9$ & $0.41 \pm 31$ & $56.4 \pm 732$ & $25.0 \pm 359$ & 74 \\
\hline
\end{tabular}

of AgNPs using Coccinia grandis and Phyllanthus emblica fruit extracts as a comparative analysis. It also ensures the ecofriendly and renewable methods for synthesis of AgNPs. As far as UV spectrum is concerned, the plant residue of
C. grandis shows deep absorptions at $442 \mathrm{~nm}$ that is considered as the maximum and the FTIR shows 1640.02 -N-H bond-amines (Coccinia grandis). $1637.45-\mathrm{N}-\mathrm{H}$ bond-amines show for Phyllanthus emblica, where these 
Table 7 Seed germination assay on AgNPs of Phyllanthus emblica

\begin{tabular}{|c|c|c|c|c|c|c|}
\hline \multirow{2}{*}{\multicolumn{2}{|c|}{$\begin{array}{l}\text { Seed germina- } \\
\text { tion }(\%)\end{array}$}} & \multicolumn{2}{|c|}{ Seedling growth (cms) } & \multirow[t]{2}{*}{ Fresh weight (gms) } & \multirow[t]{2}{*}{ Dry weight (gms) } & \multirow{2}{*}{$\begin{array}{l}\text { Relative } \\
\text { water con- } \\
\text { tent }(\%)\end{array}$} \\
\hline & & Root length & Shoot length & & & \\
\hline \multicolumn{7}{|c|}{ Cicer arietinum } \\
\hline Control & 40 & $1.09 \pm 0.7$ & $1.09 \pm 0.8$ & $196 \pm 996$ & $19.2 \pm 149$ & \multirow[t]{2}{*}{91.06} \\
\hline AgNPs & 100 & $1.03 \pm 1.8$ & $1.03 \pm 1.8$ & $440 \pm 1175$ & $14.6 \pm 164$ & \\
\hline \multicolumn{7}{|c|}{ Pisum sativum } \\
\hline Control & 80 & $0.20 \pm 0.32$ & $0.418 \pm 0.4$ & $25.5 \pm 296$ & $43.30 \pm 219$ & \multirow[t]{2}{*}{66.47} \\
\hline AgNPs & 100 & $0.27 \pm 0.7$ & $1.99 \pm 2.36$ & $39.5 \pm 577$ & $125 \pm 624$ & \\
\hline \multicolumn{7}{|c|}{ Lablab purpureus } \\
\hline Control & 20 & $0.67 \pm 0.3$ & $0.89 \pm 0.4$ & $109 \pm 479$ & $76 \pm 351$ & \multirow[t]{2}{*}{16.011} \\
\hline AgNPs & 80 & $0.89 \pm 1.1$ & $0.93 \pm 1.5$ & $109 \pm 479$ & $67.1 \pm 347$ & \\
\hline
\end{tabular}

SEED GERMINATION

Cicer arietinum and Pisum sativum

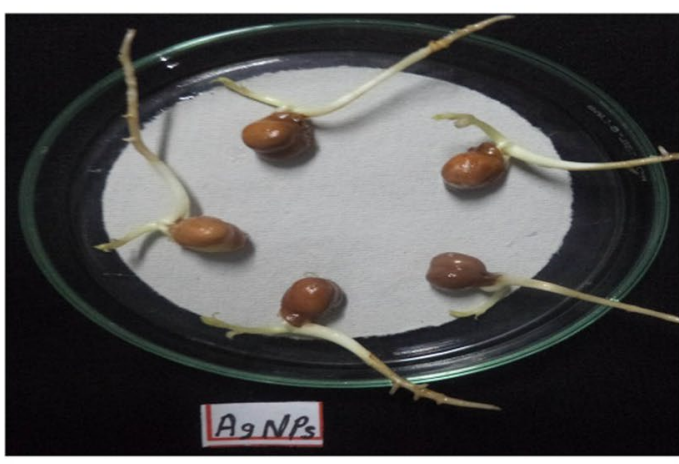

A

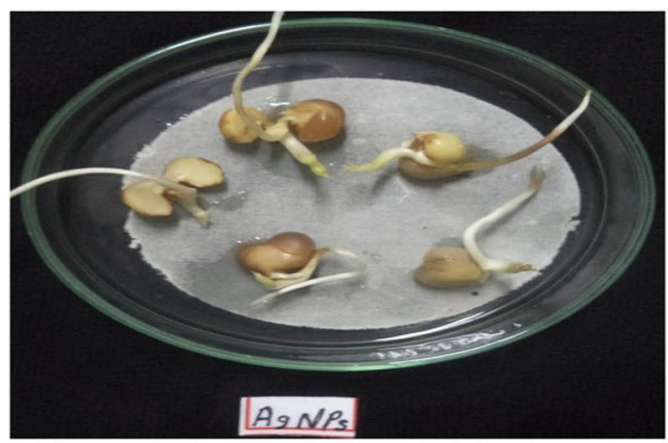

C

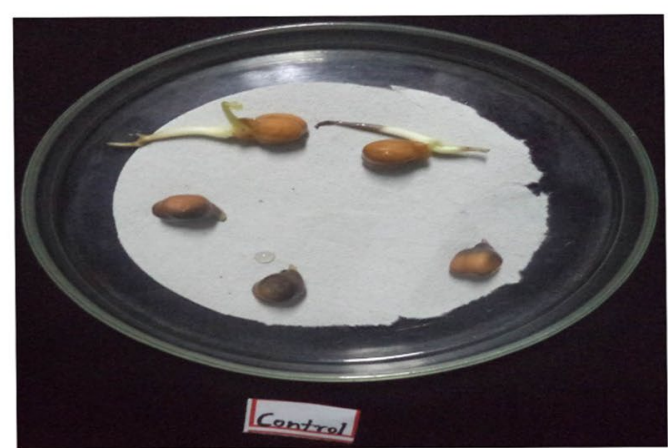

B

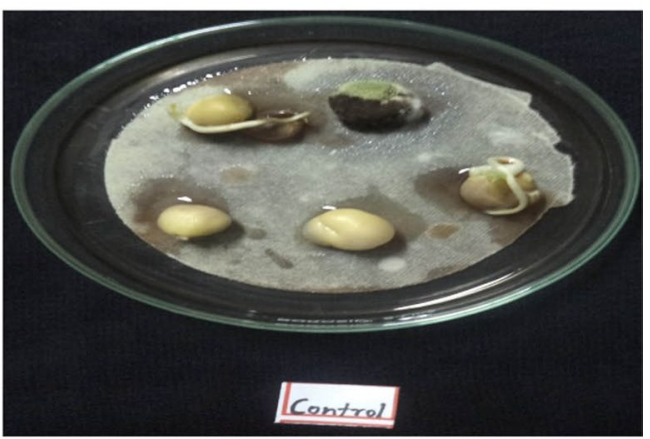

D

A and C - AgNPs mediated seed germination

$B$ and D - Without AgNPs (only water)

Fig. 15 Seed germination assay using AgNPs from Coccinea grandis

both analyses show similar result. The SEM results illustrate that AgNPs are spherical in shape. The XRD patterns are indicating the presence of AgNPs formed at crystalline nature in both these plants. The anti-oxidant being evidence for the maximum absorptions of AgNPs from Phyllanthus emblica are more effective and efficient for comprising the anti-oxidant properties. The anti-microbial assay of AgNPs (Coccinia grandis) gives you an idea about the maximum 


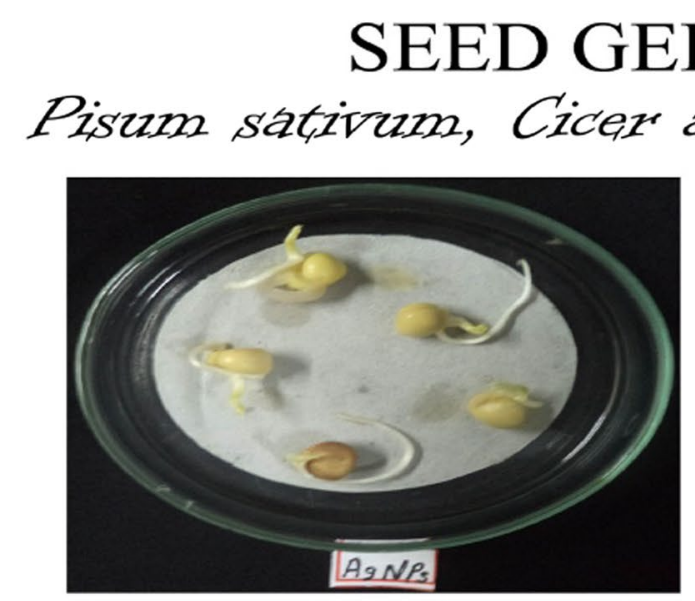

A

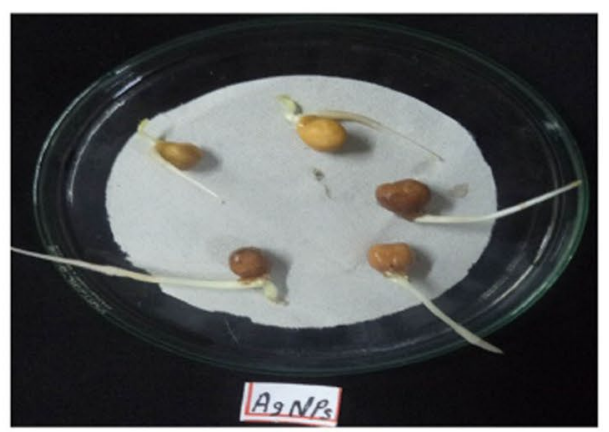

C

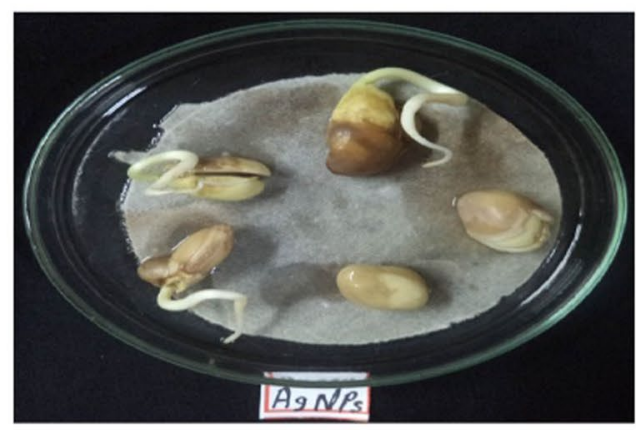

$\mathbf{E}$

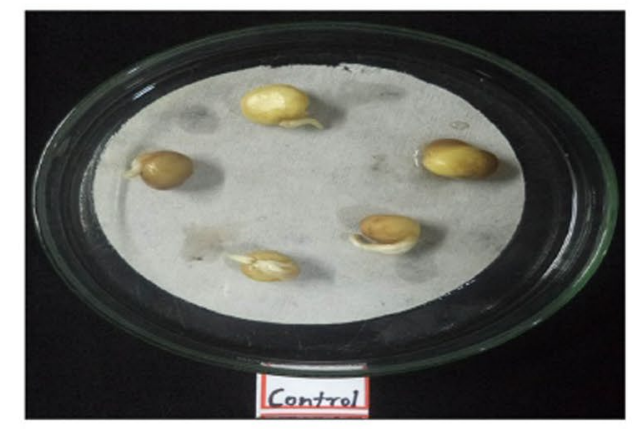

B

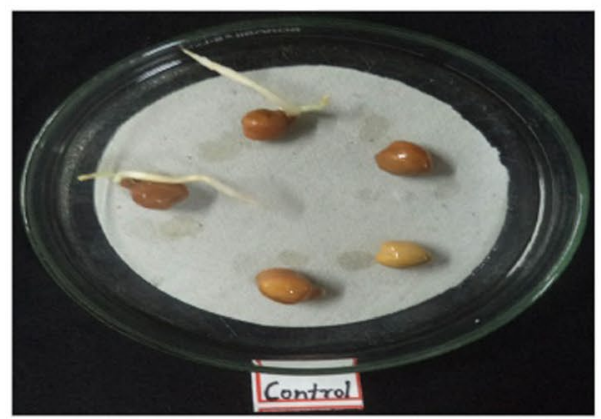

D

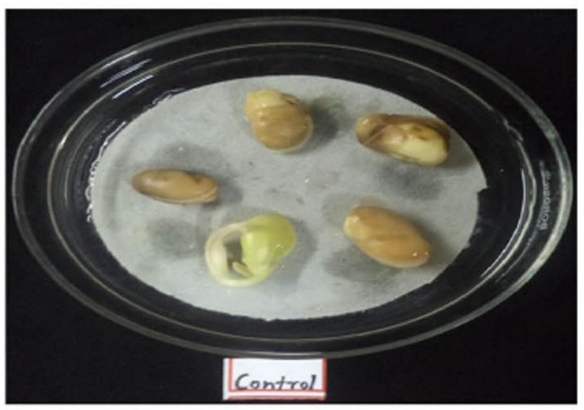

$\mathbf{F}$

\section{A, C, E - AgNPs mediated seed germination B,D,F - without AgNPs (only water)}

Fig. 16 Seed germination assay on the Phyllanthus emblica AgNPs

zone of inhibition (14 mm) Vibrio cholerae, whereas AgNPs (Phyllanthus emblica) prove the maximum inhibition at two distinct points, namely, Staphylococcus aureus and Vibrio cholerae, respectively. Seed germination assay also proofs that breaking of seed coat initiated by AgNPs is quiet effective and healthier, compared to the water-induced seeds.
Therefore, $P$. emblica give an idea about positive result in all major aspects of analysis. The reduction in shape and size can be obtained by altering with concentration of $\mathrm{AgNO}_{3}$. Moreover, synthesis or reaction time should be altered based on the color change in the initial stage. The regime of AgNPs is left dumbfounded due to multiplication of infringement 
that occurs due to uncertainty of the modern science. The AgNPs' role in biomedical and agriculture fields needs to be focused upon, since there is no much validated literature that corresponds to the right description of AgNPs. But still, there are few authentic factors and may come on by the synthesis process by biological method, where the advantage and possible triggered speculation may occur in the near future.

Acknowledgements Authors are thankful to management of St. Joseph's college for providing the nanotechnology-related analytical and instrumental facility.

\section{Compliance with ethical standards}

Conflict of interest The authors report no conflicts of interest. The authors alone are responsible for the content and writing of this article.

\section{References}

Ahmad A, Mukherjee P, Senapati S, Mandal D, Khan MI, Kumar R, Sastry M (2003) Extracellular biosynthesis of silver nanoparticles using the fungus Fusarium oxysporum. Colloids Surf B Biointerfaces. 28:3-8

Ahmed S, Ahmad M, Saifullah, Swami BL, Ikram S (2016a) Green synthesis of silver nanoparticles using Azadirachta indica aqueous leaf extract. J Radiat Res Appl Sci 9:1-7

Ahmed S, Ahmad M, Swami BL, Ikram S (2016b) A review on plants extract mediated synthesis of silver nanoparticles for antimicrobial applications: a green expertise. J Adv Res 7:17-28

Ankamwar B, Damle C, Ahmad A, Sastry M (2005) Biosynthesis of gold and silver nanoparticle using Emblica Officinalis fruit extract, their phase transfer and transmetallation in an organic solution. J Nanosci Nanotechnol 5:1665-1671

Ankanna S, Prasad TNVKV, Elumalai EK, Savithramma N (2010) Production of biogenic silver nanoparticles using Boswellia ovalifoliolata stem bark. Digest J Nanomater Biostruct 5(2):369-372

Annamalai J, Nallamuthu T (2015) Green synthesis of silver nanoparticles: characterization and determination of antibacterial potency. Appl Nanosci 6(2):1-7

Asha A, Sivaranjani T, Thirunavukkarasu P, Asha S (2016) Green synthesis of silver nanoparticle from different plants-a review. Int J Pure Appl Biosci 4(2):118-124

Barrs HD, Weatherley PE (1962) A re-examination of the relative turgidity techniques for estimating water deficits in leaves. Aust J Biol Sci $15: 413-428$

Caroling G, Vinodhini E, Mercy Ranjitham A, Shanthi P (2015) Biosynthesis of copper nanoparticles using aqueous Phyllanthus Embilica (Gooseberry) extract - characterisation and study of antimicrobial effects. Int J Nano Chem 1(2):53-63

Devika R, Elumalai S, Manikandan E, Eswaramoorthy D (2012) Biosynthesis of silver nanoparticles using the Fungus Pleurotus ostreatus and their antibacterial activity. Open Access Sci Rep 12(1):2-5

El-Chaghaby GA, Ahmad AF (2011) Biosynthesis of silver nanoparticles using pistacia lentiscus leaves extract and investigation of their antimicrobial effect. Orient J Chem 27:929-936

El-Rafie HM, Hamed MAA (2014) Antioxidant and anti-inflammatory activities of silver nanoparticles biosynthesized from aqueous leaves extracts of four Terminalia. Species. Adv Nat Sci Nanosci Nanotechnol 5:11

Ghodake GS, Deshpande NG, Lee YP, Jin ES (2010) Pear fruit extractassisted room-temperature biosynthesis of gold nanoplates. Colloids Surf B 75:584-589
Harajyoti M, Ahmed GU (2011) synthesis of silver nanoparticles and its adverse effect on seed germinations in Oryza Sativa, Vigna Radiata and Brassica Campestris. Int J Adv Biotechnol Res 2(4):404-413

Jain D, Daima HK, Kachhwaha S, Kothari SL (2009) Synthesis of plantmediated silver Nanoparticle using papaya fruit extract and evaluation of their anti microbial activities. Dig J Nanomat Biostruct 4:557-563

Janani S, Priscilla S, Shankar S, Rachan R, Brindha P, Aravind S, Anbazhagan V (2014) Spectroscopy investigation on chemo-catalytic, free radical scavenging and bactericidal properties of biogenic silver nanoparticles synthesized using Salicornia brachiata aqueous extract. Spect Acta Part A Mol Biomol Spect 118:349-355

Jayandran M, Muhamed Haneefa M, Balasubramanian V (2015) Green synthesis and characterization of Manganese nanoparticles using natural plant extracts and its evaluation of antimicrobial activity. J Appl Pharm Sci 5(12):105-110

Khanra K, Panja S, Choudhuri I, Chakraborty A, Bhattacharyya N (2016) Antimicrobial and cytotoxicity effect of silver nanoparticle synthesized by Croton bonplandianum Baill. Leaves. Nanomed J. $3(1): 15-22$

Klaus-Joerger T, Joerger R, Olsson E, Granqvist C (2001) Bacteria as workers in the living factory: metal accumulating bacteria and their potential for materials science. Trends Biotechnol 19:15-20

Kranner I, Colville L (2011) Metals and seeds: biochemical and molecular implications and their significance for seed germination. Environ Exp Bot 7(1):93-105

Kumar R, Sharma P, Kumar N (2015) Enhanced antibacterial activity of streptomycin against some human pathogens using green synthesized silver nanoparticles. Resour Eff Technol 1(2):106-115

Mohammad EKK, Fereshteh N (2016) Flavonoid content of Anthemis tinctoria and its application for green synthesis of silver nanoparticles. J Pharmacogn Phytochem 5(1):264-266

Parashar V, Parashara R, Sharma B, Pandey AC (2009) Parthenium leaf extract mediated synthesis of silver Nanoparticle: a novel approach towards weed utilization. Dig J Nanomat Biostruct 4(1):445-450

Park HJ, Kim SH, Kim HJ, Choi SH (2006) A new composition of nanosized silica-silver for control of various plant diseases. Plant Pathol J 2:25-34

Pavani K, Divya V, Veena V, Adity I, Devakinandan M (2014) Influence of bioengineered zinc nanoparticles and Zinc metal on cicer arietinum seedlings growth. Asian J Agri Biol 2(4):216-223

Ravichandran R (2010) Nanotechnology applications in food and food processing: innovative green approaches, opportunities and uncertainties for global market. Int J Green Nanotechnol Phys Chem 1:72-96

Saminathan K (2015) Biosynthesis of silver nanoparticles using soil Actinomycetes Streptomyces sp. Int J Curr Microbiol Appl Sci 4(3):1073-1083

Sulaiman GM, Mohammad AAW, Abdul-Wahed H, Ismail MM (2013) Biosynthesis, antimicrobial and cytotoxic effects of silver nanoparticles using Rosmarinus officinalis extract. Dig J Nanomat Bios 8: 273-280

Thirumurugan A, Jiflin GJ, Rajagomathi G, Tomy NA, Ramachandran S, Jaiganesh R (2010) Biotechnological synthesis of gold Nanoparticle of Azadirachta indica leaf extract. Int J Biol Technol 1(1):175-177

Veerasamy R, Xin TZ, Gunasagaran S, Xiang TF, Yang E, Jeyakumar N (2011) Biosynthesis of silver nanoparticles using mangosteen leaf extract and evaluation of their antimicrobial activities. J Saudi Chem Soc $15: 113-120$

Publisher's Note Springer Nature remains neutral with regard to jurisdictional claims in published maps and institutional affiliations. 